\title{
Singulisphaera rosea sp. nov., a planctomycete from acidic Sphagnum peat, and emended description of the genus Singulisphaera
}

\author{
Correspondence \\ Svetlana N. Dedysh \\ dedysh@mail.ru
}

\author{
Irina S. Kulichevskaya, ${ }^{1}$ Ekaterina N. Detkova, ${ }^{1}$ Paul L. E. Bodelier, ${ }^{2}$ \\ W. Irene C. Rijpstra, Jaap S. Sinninghe Damsté ${ }^{3}$ and Svetlana N. Dedysh ${ }^{1}$ \\ ${ }^{1}$ S. N. Winogradsky Institute of Microbiology, Russian Academy of Sciences, \\ Prospect 60-letya Octyabrya 7/2, Moscow 117312, Russia \\ ${ }^{2}$ Netherlands Institute of Ecology, NL3631 AC Nieuwersluis, The Netherlands \\ ${ }^{3}$ Royal Netherlands Institute for Sea Research, Department of Marine Organic Biogeochemistry, \\ PO Box 59, 1790 AB Den Burg, The Netherlands
}

\begin{abstract}
An aerobic, pink-pigmented, budding bacterium, designated strain $\mathrm{S}^{2} 6^{\top}$, was isolated from an acidic Sphagnum peat bog of north-western Russia. Cells were non-motile and spherical, occurring singly, in pairs or in short chains, and were able to attach to surfaces by means of a holdfast material. Strain $S 26^{\top}$ was a moderately acidophilic, mesophilic organism capable of growth at $\mathrm{pH} 3.2-7.1$ (optimum at $\mathrm{pH} 4.8-5.0$ ) and at $4-33^{\circ} \mathrm{C}$ (optimum at $20-26{ }^{\circ} \mathrm{C}$ ). Most sugars, several organic acids and polyalcohols were the preferred growth substrates. The major fatty acids were $C_{16: 0}, C_{18: 1} \omega 9 c$ and $C_{18: 2} \omega 6 c, 12 c$. The major neutral lipids were $n-C_{31: 9}$ hydrocarbon and squalene; the polar lipids were phosphatidylglycerol, phosphatidylcholine and components with an unknown structure. The DNA G+C content of strain S26 ${ }^{\top}$ was 62.2 mol\%. 16S rRNA gene sequence analysis showed that strain $S 26^{\top}$ is a member of the order Planctomycetales. Among taxonomically characterized representatives of this order, highest levels of $16 \mathrm{~S}$ rRNA gene sequence similarity (95.1-95.2\%) were observed with strains of the non-filamentous, peat-inhabiting planctomycete Singulisphaera acidiphila. Strain $S 26^{\top}$ could be differentiated from Singulisphaera acidiphila based on pigmentation, significant differences in substrate utilization patterns, greater tolerance of acidic conditions and the presence of $\mathrm{C}_{16: 1} \omega 9 \mathrm{c}$. Based on the data presented, strain $S 26^{\top}$ is considered to represent a novel species of the genus Singulisphaera, for which the name Singulisphaera rosea sp. nov. is proposed; the type strain is $S 26^{\top}\left(=\mathrm{DSM} 23044^{\top}=\mathrm{VKM} \mathrm{B}^{\mathrm{B}}-2599^{\top}\right)$.
\end{abstract}

Members of the order Planctomycetales are budding bacteria that possess highly distinctive cell morphology, peptidoglycan-less cell walls and a unique cell organization (Staley et al., 1992; Fuerst, 1995, 2005; Ward et al., 2006). Planctomycetes represent a numerically abundant bacterial population in northern Sphagnum-dominated wetlands (Dedysh et al., 2006; Kulichevskaya et al., 2006). Several peat-inhabiting planctomycetes have been isolated in pure culture and described as representatives of three novel species of new genera, namely Schlesneria paludicola, Singulisphaera acidiphila and Zavarzinella formosa (Kulichevskaya et al., 2007, 2008, 2009). These planctomycetes are aerobic, moderately acidophilic and mesophilic budding bacteria,

The GenBank/EMBL/DDBJ accession number for the 16S rRNA gene sequence of strain $\mathrm{S}^{\top} 6^{\top}$ is FN391026.

Three supplementary figures are available with the online version of this paper. which utilize a wide range of sugars and several polysaccharides as growth substrates.

Differential detection of planctomycetes in acidic peat bogs using newly developed group-specific 16S rRNA genetargeted fluorescent probes revealed that Singulisphaeralike micro-organisms were numerically the largest group of indigenous planctomycetes (A. O. Ivanova and S. N. Dedysh, unpublished data). They were represented by spherical cells that occurred singly, in short chains or in shapeless aggregates. We isolated a novel peat-inhabiting planctomycete of similar morphology, designated strain $\mathrm{S} 26^{\mathrm{T}}$. Despite significant morphological similarity to Singulisphaera acidiphila, cells of the novel isolate were slightly larger and colonies were pink-pigmented. Preliminary substrate utilization tests revealed that strain $\mathrm{S} 26^{\mathrm{T}}$ was capable of growth on several organic acids, a feature lacking in Singulisphaera acidiphila. Finally, a partial (approx. 500 bp) 16S rRNA gene sequence of the novel isolate showed only $95 \%$ similarity to the 
corresponding gene fragment in Singulisphaera acidiphila $\operatorname{MOB} 10^{\mathrm{T}}$. Therefore, this study was initiated to characterize strain $\mathrm{S} 26^{\mathrm{T}}$ in more detail and to determine its taxonomic position.

Strain $\mathrm{S} 26^{\mathrm{T}}$ was obtained from a peat sample collected from the top layer $(5-10 \mathrm{~cm})$ of the acidic $(\mathrm{pH} 3.8)$ Sphagnum peat bog Staroselskoye, located in the Central Forest Reserve, Tver region, north-west Russia ( $\left.56^{\circ} 58^{\prime} \mathrm{N} 32^{\circ} 30^{\prime} \mathrm{E}\right)$. The isolation procedure and the culture conditions used were as described previously (Dedysh et al., 2006; Kulichevskaya et al., 2006). The isolate was maintained on agar medium M31 (modification of medium 31 described by Staley et al., 1992) containing (per litre of distilled water): $0.1 \mathrm{~g} \mathrm{KH}_{2} \mathrm{PO}_{4}$, $20 \mathrm{ml}$ Hutner's basal salts, $1.0 \mathrm{~g} \mathrm{~N}$-acetylglucosamine, $0.1 \mathrm{~g}$ peptone, $0.1 \mathrm{~g}$ yeast extract and $15 \mathrm{~g}$ agar-agar (Difco), $\mathrm{pH}$ 5.8. Singulisphaera acidiphila MOB $10^{\mathrm{T}}$ (Kulichevskaya et al., 2008) was used as a reference strain in our study and was maintained on the same medium.

Morphological observations and cell size measurements were made with a Zeiss Axioplan 2 microscope and Axiovision 4.2 software (Zeiss). Physiological tests were performed in liquid medium M31. Growth of strain $\mathrm{S} 26^{\mathrm{T}}$ was monitored by nephelometry at $600 \mathrm{~nm}$ in an Eppendorf BioPhotometer for 7-14 days under a variety of conditions, including $4-37^{\circ} \mathrm{C}, \mathrm{pH} 3.0-8.0$ and $\mathrm{NaCl}$ concentrations of $0-4.0 \%(\mathrm{w} / \mathrm{v})$. Variations in $\mathrm{pH}$ were achieved by adding $0.1 \mathrm{M}$ solutions of $\mathrm{H}_{2} \mathrm{SO}_{4}$ and $\mathrm{KOH}$. Carbon source utilization was determined by using liquid mineral medium (MM) supplemented with respective carbon sources $(0.05 \%, \mathrm{w} / \mathrm{v}) . \mathrm{MM}$ contained (per litre distilled water): $0.1 \mathrm{~g}$ $\mathrm{KH}_{2} \mathrm{PO}_{4}, 0.1 \mathrm{~g}\left(\mathrm{NH}_{4}\right)_{2} \mathrm{SO}_{4}, 0.1 \mathrm{~g} \mathrm{MgSO}_{4} .7 \mathrm{H}_{2} \mathrm{O}$ and $1 \mathrm{ml}$ of metal salt solution '44' (Staley et al., 1992), $\mathrm{pH}$ adjusted to 5.5. Cultivation was done in $100 \mathrm{ml}$ flasks containing $10 \mathrm{ml}$ medium. Cultures were incubated at $25{ }^{\circ} \mathrm{C}$ for $2-3$ weeks on a shaker. Nitrogen sources were tested by using liquid MM with $0.05 \%$ glucose in which $\left(\mathrm{NH}_{4}\right)_{2} \mathrm{SO}_{4}$ was replaced with one of the following compounds at a concentration of $0.05 \%$ $(\mathrm{w} / \mathrm{v}): \mathrm{KNO}_{3}, \mathrm{KNO}_{2}$, urea or one of the amino acids listed in the species description below. The ability to degrade different biopolymers was determined as described for Singulisphaera acidiphila (Kulichevskaya et al., 2008). Oxidative and fermentative utilization of carbohydrates was determined as described for the Hugh-Leifson test (Gerhardt, 1981) and by using the API 20NE kit (bioMérieux). Enzyme activities were examined by using the API ZYM kit (bioMérieux). Cultures were tested for growth under anaerobic conditions in anaerobic jars by using AnaeroGen anaerobic system envelopes (Oxoid). Susceptibility to antibiotics was determined on M31 agar plates by using discs containing the following compounds: ampicillin $(10 \mu \mathrm{g})$, gentamicin $(10 \mu \mathrm{g})$, kanamycin $(30 \mu \mathrm{g})$, neomycin $(10 \mu \mathrm{g})$, novobiocin $(30 \mu \mathrm{g})$, streptomycin $(10 \mu \mathrm{g})$, chloramphenicol $(30 \mu \mathrm{g})$ and lincomycin $(10 \mu \mathrm{g})$ (Oxoid).

For analyses of fatty acids, and neutral and polar lipids, strain $\mathrm{S} 26^{\mathrm{T}}$ and Singulisphaera acidiphila $\mathrm{MOB}^{\mathrm{T}} \mathrm{T}^{\mathrm{T}}$ were grown in parallel in liquid medium M31 under identical conditions. Phospholipid fatty acids were analysed as described for Schlesneria paludicola (Kulichevskaya et al., 2007). The positions of unsaturation in monoenoic and dienoic fatty acids were determined as described by Bodelier et al. (2009). Batches of cell material were subjected to base and acid hydrolysis and, subsequently, were analysed for fatty acids and neutral lipids. Acid hydrolysis was performed in $5 \%(\mathrm{v} / \mathrm{v}) \mathrm{HCl} /$ methanol by refluxing for $3 \mathrm{~h}$. Base hydrolysis was performed by treatment with $1 \mathrm{M} \mathrm{KOH}$ in $96 \%$ methanol by refluxing for $1 \mathrm{~h}$. For neutral lipid analysis, the procedures described by Sinninghe Damsté et al. (2004) were used. Intact polar lipids were analysed by LC/MS according to Sturt et al. (2004) with some modifications. An Agilent 1200 series liquid chromatograph, equipped with a thermostatted auto-injector and column oven, was used, coupled to a Thermo LTQ XL linear ion trap with Ion Max source with electrospray ionization probe (Thermo Scientific).

Genomic DNA of strain $526^{\mathrm{T}}$ was extracted as described by Marmur (1961). The G+C content of the DNA was determined by means of thermal denaturation by using a Unicam SP1800 spectrophotometer at a heating rate of $0.5{ }^{\circ} \mathrm{C} \min ^{-1}$ and was calculated according to Owen et al. (1969). DNA of Escherichia coli K-12 (G+C content $51.7 \mathrm{~mol} \%$ ) was used as the standard. PCR-mediated amplification of the 16S rRNA gene from positions 28 to 1491 (numbering according to the International Union of Biochemistry nomenclature for the E. coli $16 \mathrm{~S}$ rRNA gene) was performed by using primers $9 \mathrm{f}$ and $1492 \mathrm{r}$ and the reaction conditions described by Weisburg et al. (1991). 16S rRNA gene amplicons were purified by using QIAquick spin columns (Qiagen) and sequenced on an ABI Prism 377 DNA sequencer with BigDye terminator chemistry, as specified by the manufacturer (PE Applied Biosystems). Phylogenetic analysis was carried out by using the ARB program package (Ludwig et al., 2004).

On agar medium M31, strain S26 ${ }^{\mathrm{T}}$ formed raised, pinkpigmented, circular colonies with an entire edge and a smooth surface. No gliding motility was observed in cultures of the novel isolate. Liquid cultures displayed light-pink turbidity. Mature cells of strain S26 ${ }^{\mathrm{T}}$ were spherical and typically varied in size from 1.8 to $3.2 \mu \mathrm{m}$, although some cells in old cultures were up to $3.5 \mu \mathrm{m}$ in diameter (Fig. 1a). Cells were non-motile and encapsulated. They reproduced by budding and occurred singly, in pairs or in short chains containing up to $4-5$ cells. However, these cell chains were unstable and no filaments were observed in cultures of strain S26 ${ }^{\mathrm{T}}$. Examination of old cultures grown on agar plates revealed the presence of an amorphous holdfast substance excreted from the poles of many cells (Fig. 1b). Similar holdfast production has been reported for Pirellula-like bacteria (Schlesner, 1994) as well as for Singulisphaera acidiphila and Z. formosa (Kulichevskaya et al., 2008, 2009). This holdfast substance enables the cells to attach to surfaces or to form aggregates by attaching to each other. 

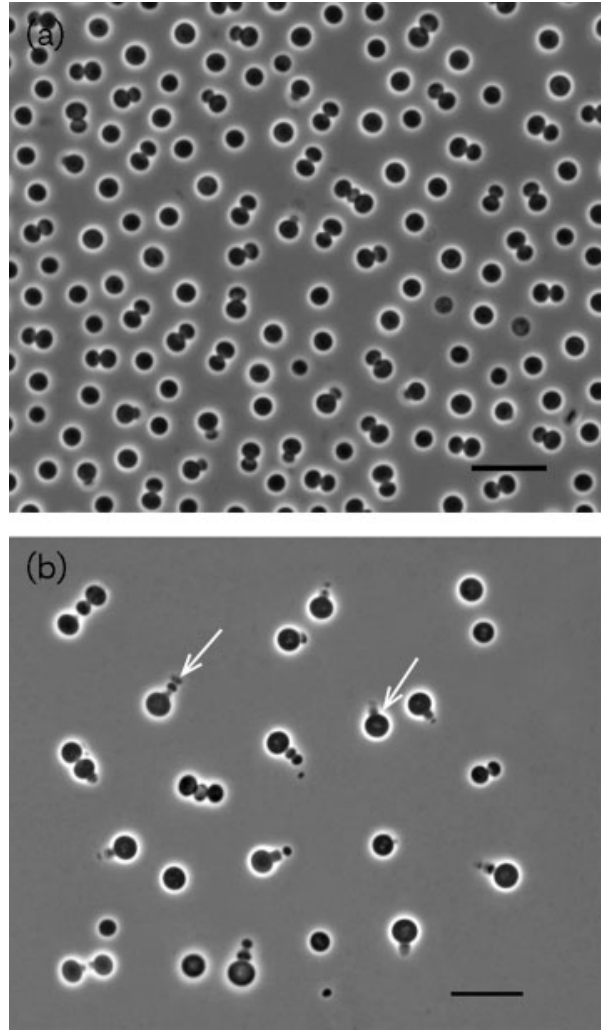

Fig. 1. Phase-contrast micrographs of cells of strain $S 26^{\top}$ grown for 7 days in liquid culture (a) and for 2 weeks on agar medium (b); white arrows point to an amorphous holdfast substance excreted by the cells grown on agar medium. Bars, $10 \mu \mathrm{m}$.

Strain S26 ${ }^{\mathrm{T}}$ was an obligately aerobic chemoheterotroph. Similar to Singulisphaera acidiphila, it was not capable of fermenting carbohydrates. However, strain $\mathrm{S} 26^{\mathrm{T}}$ grew well under microaerobic conditions.

The list of carbon substrates tested in our experiments and the results are given in the species description below. Most sugars, several organic acids and sugar alcohols were the preferable growth substrates. Strain $S 26^{T}$ was capable of hydrolysing starch, laminarin, chondroitin sulfate, aesculin, gelatin and pullulan but not xylan, pectin, chitin or cellulose. It was positive for catalase activity, but negative for cytochrome oxidase and urease activities and dissimilatory nitrate reduction. Growth factors were not required. Ammonia, nitrate, $\mathrm{N}$-acetylglucosamine, Bacto peptone, Bacto yeast extract, alanine, aspartate, arginine, glutamine, threonine, tryptophan, glycine, isoleucine, lysine, phenylalanine, proline and valine were utilized as nitrogen sources. Nitrite was not utilized. The following enzyme activities (API ZYM) were detected in strain $\mathrm{S} 26^{\mathrm{T}}$ : alkaline phosphatase, acid phosphatase, esterase, esterase lipase, leucine arylamidase, valine arylamidase, phosphohydrolase, $\mathrm{N}$ acetyl- $\beta$-glucosaminidase and $\beta$-glucosidase. The following enzyme activities were absent: arginine hydrolase, lipase, trypsin, chymotrypsin, cystine arylamidase, $\alpha$-galactosidase, $\beta$-glucuronidase, $\alpha$-glucosidase, $\alpha$-mannosidase and $\alpha$-fucosidase. The isolate was resistant to ampicillin, streptomycin, chloramphenicol, neomycin and novobiocin, but sensitive to lincomycin, kanamycin and gentamicin.

Strain $\mathrm{S} 26^{\mathrm{T}}$ grew in the $\mathrm{pH}$ range 3.2-7.1, with optimum growth at $\mathrm{pH} 4.8-5.0$ (see Supplementary Fig. S1 in IJSEM Online), and was therefore more acidophilic than Singulisphaera acidiphila. The temperature range for growth of strain $\mathrm{S} 26^{\mathrm{T}}$ was $4-33{ }^{\circ} \mathrm{C}$, with optimum growth at $20-26^{\circ} \mathrm{C}$. Compared with Singulisphaera acidiphila, strain $\mathrm{S} 26^{\mathrm{T}}$ was slightly less sensitive to salt stress. Growth inhibition of 50$80 \%$ was observed in the presence of $\mathrm{NaCl}$ in the medium at concentrations of $0.8-1.0 \%(\mathrm{w} / \mathrm{v})$, whereas complete inhibition of growth occurred at $\mathrm{NaCl}$ concentrations above $1.0 \%(\mathrm{w} / \mathrm{v})$.

The major fatty acids of strain $\mathrm{S} 26^{\mathrm{T}}$ recovered after both base and acid hydrolysis were $\mathrm{C}_{16: 0}, \mathrm{C}_{18: 1} \omega 9 c$ and $\mathrm{C}_{18: 2} \omega 6 c, 12 c$ (Table 1, Supplementary Fig. S2, available in IJSEM Online). High levels of these fatty acids were also characteristic for Singulisphaera acidiphila (Kulichevskaya et al., 2008). However, the presence of $\mathrm{C}_{16: 1} \omega 9 \mathrm{c}$ in the fatty acid profile of strain $\mathrm{S} 26^{\mathrm{T}}$ contrasted with that of Singulisphaera acidiphila. Analysis of the intact polar lipids by LC/MS (Sturt et al., 2004) revealed the presence of phosphatidylglycerol, phosphatidylcholine and polar lipids of unknown structure with similar distributions for strain $\mathrm{S} 26^{\mathrm{T}}$ and Singulisphaera acidiphila $\mathrm{MOB} 10^{\mathrm{T}}$ (Supplementary Fig. S3, available in IJSEM Online). Major neutral lipids of strain $\mathrm{S} 26^{\mathrm{T}}$ were an $n-C_{31: 9}$ hydrocarbon and squalene (Supplementary Fig. S2), which are also the dominant neutral lipids of Singulisphaera

Table 1. Fatty acid composition (\%) of strain $S 26^{\top}$ and Singulisphaera acidiphila MOB $10^{\top}$

Major fatty acids are shown in bold after base and acid hydrolysis of cell material. The phospholipid fatty acid composition (i.e. after Bligh-Dyer extraction, separation and hydrolysis of the methanol fraction) was nearly identical. Fatty acids comprising $<0.1 \%$ of the total were not included. -, Not detected.

\begin{tabular}{|c|c|c|c|c|}
\hline \multirow[t]{2}{*}{ Fatty acid } & \multicolumn{2}{|c|}{ Strain $526^{\mathrm{T}}$} & \multicolumn{2}{|c|}{$\begin{array}{c}\text { Singulisphaera } \\
\text { acidiphila MOB10 }\end{array}$} \\
\hline & Base & Acid & Base & Acid \\
\hline $\mathrm{C}_{14: 0}$ & 5.7 & 5.2 & 1.8 & 1.8 \\
\hline $\mathrm{C}_{15: 0}$ & 0.3 & 0.3 & 0.4 & 0.4 \\
\hline iso- $\mathrm{C}_{16: 0}$ & - & - & 0.4 & 0.5 \\
\hline $\mathrm{C}_{16: 1} \omega 9 c$ & 5.4 & 4.5 & 0.1 & 0.1 \\
\hline $\mathrm{C}_{16: 1} \omega 7 c$ & 0.7 & 0.6 & 1.4 & 1.3 \\
\hline$C_{16: 0}$ & 27.4 & 28.3 & 33.6 & 33.1 \\
\hline $\mathrm{C}_{17: 1} \omega 7 c$ & 0.3 & 0.4 & 0.4 & 0.5 \\
\hline $\mathrm{C}_{17: 0}$ & 0.2 & 0.3 & 0.2 & 0.2 \\
\hline $\mathrm{C}_{18: 2} \omega 6 c, 12 c$ & 11.6 & 13.3 & 11.6 & 11.9 \\
\hline $\mathrm{C}_{18: 1} \omega 9 c$ & 41.8 & 40.2 & 42.7 & 42.8 \\
\hline $\mathrm{C}_{18: 1} \omega 9 t$ & 0.5 & 0.5 & 0.9 & 0.8 \\
\hline $\mathrm{C}_{18: 0}$ & 6.3 & 6.5 & 6.5 & 6.5 \\
\hline
\end{tabular}


acidiphila (Kulichevskaya et al., 2008). Base hydrolysis of the residue following extraction released, in addition to the characteristic suite of fatty acids, the uncommon 27hydroxy-octacosanoic acid at a relatively high abundance. Again, this was also observed for Singulisphaera acidiphila (Kulichevskaya et al., 2008).

Comparative sequence analysis of the $16 \mathrm{~S}$ rRNA gene showed that strain $\mathrm{S} 26^{\mathrm{T}}$ is a member of the order Planctomycetales and belongs to a phylogenetic cluster defined by the genera Isosphaera, Aquisphaera and Singulisphaera (Fig. 2). At the time of writing, this cluster contained three recognized representatives, namely Isosphaera pallida (a thermophilic filamentous neutrophile from hot springs; Giovannoni et al., 1987), Aquisphaera giovannonii (a mesophilic non-filamentous neutrophile from the sediments of a freshwater aquarium; Bondoso et al., 2011) and Singulisphaera acidiphila (a non-filamentous acidophile from northern peatlands; Kulichevskaya et al., 2008). Levels of 16S rRNA gene sequence similarity between strain $\mathrm{S} 26^{\mathrm{T}}$ and strains of I. pallida and A. giovannonii were 89.0 and $92.0-92.4 \%$, respectively, whereas the corresponding values between strain $226^{\mathrm{T}}$ and strains of Singulisphaera acidiphila were 95.1-95.2\%. Among taxonomically uncharacterized planctomycetes, the highest level of $16 \mathrm{~S}$ rRNA gene sequence similarity $(96.8 \%)$ was observed with Isosphaera-like isolate C2-3 from a laboratory ampicillin solution (Wang et al., 2002). In a maximum-likelihood analysis, this latter isolate clustered together with strain $\mathrm{S} 26^{\mathrm{T}}$. The use of other algorithms, however, failed to produce a consistent affiliation of isolate C2-3 to strain $\mathrm{S} 26^{\mathrm{T}}$. Given that isolate $\mathrm{C} 2-3$ is nonpigmented (Wang et al., 2002), it is unlikely to be a member of the same species as strain $S 26^{\mathrm{T}}$. The DNA G $+\mathrm{C}$ content of strain $\mathrm{S} 26^{\mathrm{T}}$ was $62.2 \mathrm{~mol} \%$.
In summary, our novel isolate from acidic peat was morphologically, phenotypically and phylogenetically most similar to Singulisphaera acidiphila. However, in contrast to the latter planctomycete, strain $S 26^{\mathrm{T}}$ was pigmented, was able to utilize organic acids and starch, had greater tolerance to acidic conditions and contained $\mathrm{C}_{16: 1} \omega 9 c$. We therefore suggest that strain $\mathrm{S} 26^{\mathrm{T}}$ be classified as a representative of a novel species of the genus Singulisphaera, for which the name Singulisphaera rosea sp. nov. is proposed. The characteristics that differentiate this novel species from Singulisphaera acidiphila are summarized in Table 2.

\section{Emended description of the genus Singulisphaera Kulichevskaya et al. 2008}

Singulisphaera (Sin.gu.li.spha.e'ra. L. adj. singuli single, separate; L. fem. n. sphaera sphere; N.L. fem. n. Singulisphaera a single spherical cell).

Spherical cells that occur singly, in pairs, in short chains or as shapeless aggregates. Non-motile. Reproduce by budding. Stalk-like structures are absent. Attach to surfaces by means of amorphous holdfast material. Encapsulated. Colonies are colourless or pink-coloured. Chemo-organotrophic aerobes. Capable of growth under microaerobic conditions. Catalase-positive. Cytochrome oxidase- and urease-variable. Dissimilatory nitrate reduction is negative. Moderately acidophilic and mesophilic. Sensitive to $\mathrm{NaCl}$. The major quinone is MK-6. The major fatty acids are $\mathrm{C}_{16: 0}, \mathrm{C}_{18: 1} \omega 9 c$ and $\mathrm{C}_{18: 2} \omega 6 c, 12 c$, with $\mathrm{C}_{18: 2} \omega 6 c, 12 c$ being characteristic of the genus. The major neutral lipids are $\mathrm{n}-\mathrm{C}_{31: 9}$ hydrocarbon and squalene. The polar lipids are phosphatidylglycerol, phosphatidylcholine and polar lipids with an unknown structure. The genus is a member of the phylum Planctomycetes, order Planctomycetales, family

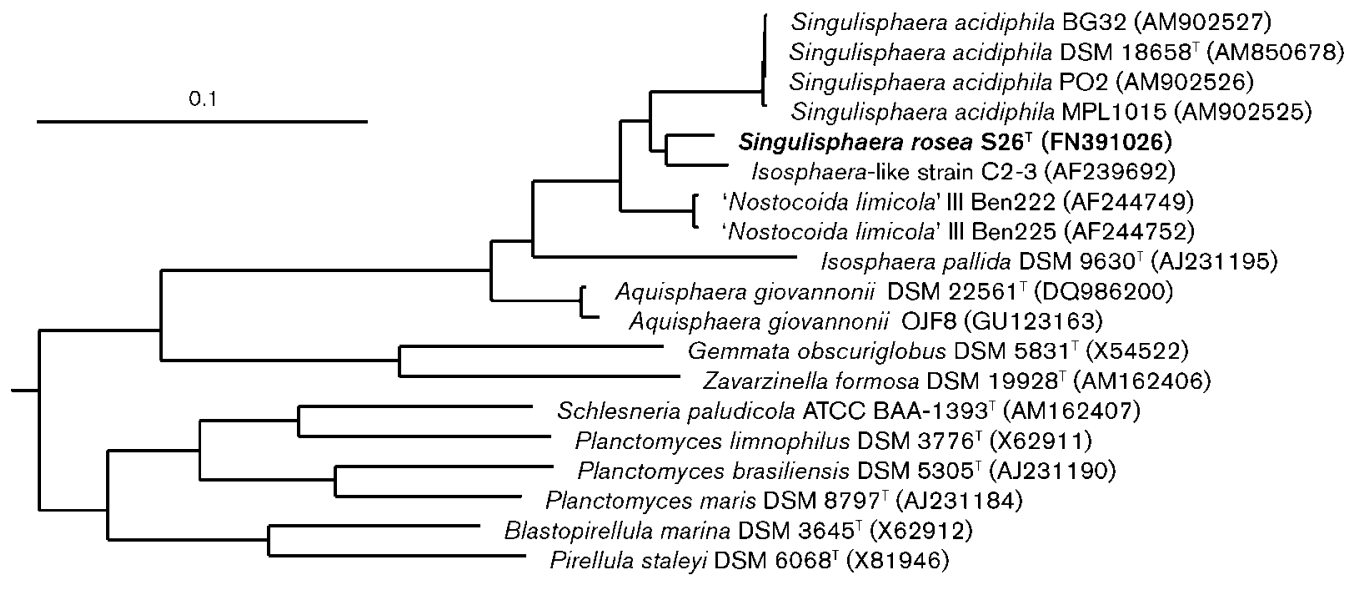

Fig. 2. $16 \mathrm{~S}$ rRNA gene-based maximum-likelihood tree showing the phylogenetic position of strain $\mathrm{S} 26^{\top}$ in relation to Singulisphaera acidiphila, Isosphaera pallida, Aquisphaera giovannonii and other representatives of the order Planctomycetales. Five anammox-planctomycetes, i.e. 'Candidatus Scalindua brodae' (AY254883), 'Candidatus Scalindua sorokinii' (AY257181), 'Candidatus Scalindua wagneri' (AY254882), 'Candidatus Brocadia anammoxidans' (AF375994) and 'Candidatus Kuenenia stuttgartiensis' (AF375995), were used as an outgroup (not shown). Bar, 0.1 substitutions per nucleotide position. 
Table 2. Differential characteristics of strain $S 26^{\top}$ and Singulisphaera acidiphila

Taxa: $1, \mathrm{~S} 26^{\mathrm{T}} ; 2$, Singulisphaera acidiphila [data from Kulichevskaya et al. (2008)].

\begin{tabular}{|c|c|c|}
\hline Characteristic & 1 & 2 \\
\hline Cell diameter $(\mu \mathrm{m})^{*}$ & $1.8-3.2$ & $1.6-2.6$ \\
\hline Arrangement of cells & $\begin{array}{l}\text { Single, in pairs or in } \\
\text { short chains }\end{array}$ & $\begin{array}{l}\text { Single or in } \\
\text { pairs }\end{array}$ \\
\hline Colony pigmentation & Pink & Unpigmented \\
\hline Salinity tolerance (\%) & $<1.0$ & $<0.2-0.5$ \\
\hline $\begin{array}{l}\mathrm{pH} \text { growth range } \\
\text { (optimum) }\end{array}$ & $\begin{array}{c}3.2-7.1 \\
(4.8-5.0)\end{array}$ & $\begin{array}{c}4.2-7.5 \\
(5.0-6.2)\end{array}$ \\
\hline \multicolumn{3}{|l|}{ Utilization of: } \\
\hline Raffinose & + & - \\
\hline Succinate & + & - \\
\hline Fumarate & + & - \\
\hline Malate & + & - \\
\hline Citrate & + & - \\
\hline Starch & + & - \\
\hline Pectin & - & + \\
\hline Dulcitol & + & - \\
\hline Sorbitol & + & - \\
\hline Mannitol & + & - \\
\hline Presence of $C_{16: 1} \omega 9 c$ & + & - \\
\hline $\begin{array}{l}\text { DNA G + C content } \\
(\mathrm{mol} \%)\end{array}$ & 62.2 & $57.7-59.9$ \\
\hline
\end{tabular}

${ }^{\star}$ Cell sizes refer to cells in exponential growth phase.

Planctomycetaceae, and includes two species, Singulisphaera acidiphila and Singulisphaera rosea. The type species is Singulisphaera acidiphila.

\section{Description of Singulisphaera rosea sp. nov.}

Singulisphaera rosea (ro'se.a. L. fem. adj. rosea pinkcoloured, rosy).

Mature cells are $1.8-3.2 \mu \mathrm{m}$ in diameter. Utilizes the following carbon sources $(0.05 \%, \mathrm{w} / \mathrm{v})$ : D-glucose, Dfructose, D-galactose, lactose, $\mathrm{D}$-arabinose, cellobiose, maltose, raffinose, L-sorbose, D-mannose, melibiose, L-rhamnose, D-ribose, DL-sucrose, D-xylose, $\mathrm{N}$-acetylglucosamine, salicin, citrate, fumarate, lactate, malate, pyruvate, succinate, dulcitol, mannitol, sorbitol, L-arginine and L-glutamine. Unable to utilize glycerol, methanol, ethanol, glucuronic acid, acetate, benzoate, caproate, formate, formaldehyde, galacturonate, propionate, $\mathrm{L}$-alanine, $\mathrm{L}$-asparagine, aspartate, L-cysteine, L-cystine, L-glycine, L-histidine, L-isoleucine, Lleucine, DL-lysine, L-methionine, L-norleucine, DL-ornithine, L-phenylalanine, L-proline, L-serine, L-threonine, L-tryptophan, L-tyrosine and DL-valine. Hydrolyses starch, laminarin, chondroitin sulfate, aesculin, gelatin and pullulan, but not pectin, xylan, chitin or cellulose. Positive for the following enzyme activities: alkaline phosphatase, acid phosphatase, esterase, esterase lipase, leucine arylamidase, valine arylamidase, phosphohydrolase, $N$-acetyl- $\beta$-glucosaminidase and $\beta$-glucosidase (API ZYM). Utilizes the following nitrogen sources $(0.05 \%$, w/v): ammonia, nitrate, $N$-acetylglucosamine, Bacto peptone, Bacto yeast extract, $\mathrm{L}$-alanine, aspartate, L-arginine, L-glutamine, L-threonine, L-tryptophan, L-glycine, L-isoleucine, DL-lysine, L-phenylalanine, L-proline and DLvaline. Nitrite is not utilized. Vitamins are not required. Resistant to ampicillin, streptomycin, chloramphenicol, neomycin and novobiocin, but sensitive to lincomycin, kanamycin and gentamicin. Grows at $\mathrm{pH}$ 3.2-7.1 (optimum at $\mathrm{pH} 4.8-5.0$ ) and at $4-33{ }^{\circ} \mathrm{C}$ (optimum at $20-26{ }^{\circ} \mathrm{C}$ ). $\mathrm{NaCl}$ inhibits growth at concentrations above $1 \%(\mathrm{w} / \mathrm{v})$. The predominant fatty acid is $\mathrm{C}_{16: 1} \omega 9 c$.

The type strain is $\mathrm{S} 26^{\mathrm{T}}\left(=\mathrm{DSM} 23044^{\mathrm{T}}=\mathrm{VKM} \mathrm{B}-2599^{\mathrm{T}}\right)$, isolated from the Sphagnum peat bog Staroselskoye, Tver region, north-west Russia. The DNA G $+\mathrm{C}$ content of the type strain is $62.2 \mathrm{~mol} \%$.

\section{Acknowledgements}

This research was supported by the Program 'Molecular and Cell Biology' of Russian Academy of Sciences, and Rosnauka project no. 02.740.11.0023. We thank Kees Hordijk for technical assistance with fatty acid analysis.

\section{References}

Bodelier, P. L. E., Gillisen, M. J., Hordijk, K., Damsté, J. S., Rijpstra, W. I. C., Geenevasen, J. A. J. \& Dunfield, P. F. (2009). A reanalysis of phospholipid fatty acids as ecological biomarkers for methanotrophic bacteria. ISME J 3, 606-617.

Bondoso, J., Albuquerque, L., Nobre, M. F., Lobo-da-Cunha, A., da Costa, M. S. \& Lage, O. M. (2011). Aquisphaera giovannonii gen. nov., sp. nov., a novel planctomycete isolated from a freshwater aquarium. Int J Syst Evol Microbiol 61, 2844-2850.

Dedysh, S. N., Pankratov, T. A., Belova, S. E., Kulichevskaya, I. S. \& Liesack, W. (2006). Phylogenetic analysis and in situ identification of bacteria community composition in an acidic Sphagnum peat bog. Appl Environ Microbiol 72, 2110-2117.

Fuerst, J. A. (1995). The planctomycetes: emerging models for microbial ecology, evolution and cell biology. Microbiology 141, 14931506.

Fuerst, J. A. (2005). Intracellular compartmentation in planctomycetes. Annu Rev Microbiol 59, 299-328.

Gerhardt, P. (1981). Manual of Methods for General Bacteriology. Washington, DC: American Society for Microbiology.

Giovannoni, S. J., Schabtach, E. \& Castenholz, R. W. (1987). Isosphaera pallida, gen. nov., and comb. nov., a gliding, budding eubacterium from hot springs. Arch Microbiol 147, 276-284.

Kulichevskaya, I. S., Pankratov, T. A. \& Dedysh, S. N. (2006). Detection of representatives of the Planctomycetes in Sphagnum peat bogs by molecular and cultivation approaches. Microbiology (English translation of Mikrobiologiya) 75, 329-335.

Kulichevskaya, I. S., Ivanova, A. O., Belova, S. E., Baulina, O. I., Bodelier, P. L. E., Rijpstra, W. I. C., Sinninghe Damsté, J. S., Zavarzin, G. A. \& Dedysh, S. N. (2007). Schlesneria paludicola gen. nov., sp. nov., the first acidophilic member of the order Planctomycetales, from Sphagnum-dominated boreal wetlands. Int J Syst Evol Microbiol 57, 2680-2687. 
Kulichevskaya, I. S., Ivanova, A. O., Baulina, O. I., Bodelier, P. L. E., Damsté, J. S. \& Dedysh, S. N. (2008). Singulisphaera acidiphila gen. nov., sp. nov., a non-filamentous, Isosphaera-like planctomycete from acidic northern wetlands. Int J Syst Evol Microbiol 58, 1186-1193.

Kulichevskaya, I. S., Baulina, O. I., Bodelier, P. L. E., Rijpstra, W. I. C., Damsté, J. S. \& Dedysh, S. N. (2009). Zavarzinella formosa gen. nov., sp. nov., a novel stalked, Gemmata-like planctomycete from a Siberian peat bog. Int J Syst Evol Microbiol 59, 357-364.

Ludwig, W., Strunk, O., Westram, R., Richter, L., Meier, H., Yadhukumar, Buchner, A., Lai, T., Steppi, S. \& other authors (2004). ARB: a software environment for sequence data. Nucleic Acids Res 32, 1363-1371.

Marmur, J. (1961). A procedure for the isolation of deoxyribonucleic acid from micro-organisms. J Mol Biol 3, 208-218.

Owen, R. J., Hill, L. R. \& Lapage, S. P. (1969). Determination of DNA base compositions from melting profiles in dilute buffers. Biopolymers 7, 503-516.

Schlesner, H. (1994). The development of media suitable for the microorganisms morphologically resembling Planctomyces spp., Pirellula spp., and other Planctomycetales from various aquatic habitats using dilute media. Syst Appl Microbiol 17, 135-145.

Sinninghe Damsté, J. S., Rijpstra, W. I. C., Schouten, S., Fuerst, J. A., Jetten, M. S. M. \& Strous, M. (2004). The occurrence of hopanoids in planctomycetes: implications for the sedimentary biomarker record. Org Geochem 35, 561-566.
Staley, J. T., Fuerst, J. A., Giovannoni, S. \& Schlesner, H. (1992). The order Planctomycetales and the genera Planctomyces, Pirellula, Gemmata and Isosphaera. In The Prokaryotes: a Handbook on the Biology of Bacteria: Ecophysiology, Isolation, Identification, Applications, 2nd edn, pp. 3710-3731. Edited by A. Balows, H. Truper, M. Dworkin, W. Harder \& K. H. Schleifer. New York: Springer.

Sturt, H. F., Summons, R. E., Smith, K., Elvert, M. \& Hinrichs, K.-U. (2004). Intact polar membrane lipids in prokaryotes and sediments deciphered by high-performance liquid chromatography/electrospray ionization multistage mass spectrometry-new biomarkers for biogeochemistry and microbial ecology. Rapid Commun Mass Spectrom 18, 617-628.

Wang, J., Jenkins, C., Webb, R. I. \& Fuerst, J. A. (2002). Isolation of Gemmata-like and Isosphaera-like planctomycete bacteria from soil and freshwater. Appl Environ Microbiol 68, 417-422.

Ward, N., Staley, J. T., Fuerst, J. A., Giovannoni, S., Schlesner, H. \& Stackebrandt, E. (2006). The order Planctomycetales, including the genera Planctomyces, Pirellula, Gemmata and Isosphaera and the Candidatus genera Brocadia, Kuenenia and Scalindua. In The Prokaryotes: a Handbook on the Biology of Bacteria, 3rd edn, vol. 7, pp. 757-793. Edited by M. Dworkin, S. Falkow, E. Rosenberg, K. H. Schleifer \& E. Stackebrandt. New York: Springer.

Weisburg, W. G., Barns, S. M., Pelletier, D. A. \& Lane, D. J. (1991). $16 \mathrm{~S}$ ribosomal DNA amplification for phylogenetic study. J Bacteriol 173, 697-703. 